This, in the mouth of a psycho-analyst, will bo understood to mean sexual tendencies, and as the warning occurs immediately after Dr. Jones has been treating of "the question of sexuality in children," it is natural to suppose that he did mean sexual tendencies. If Dr. Jones did not mean that children are to be encouraged to masturbate, he has expressed himself very unfortunately, for his words, as reported, will bear this interpretation, and there is nothing in the "theory" of psycho analysis to discountenance it.

April 22nd, 1916. I am, Sir, yours faithfully.

Chas. A. Mercier.

\section{THE TRANSLATION OF JUNG'S ANALYTICAL PSYCHOLOGY.}

\section{To the Editor of THE LANCET.}

SrR,-The Oollected Papers on Analytical Psychology by Dr. C. G. Jung I find to be announced in a publisher's list as translated by Dr. Constance $\mathrm{E}$. Long. Of nine papers (263 pages) especially translated from the German for this book six (224 pages) were done entirely by my wife and myself ; a further two (26 pages) were completely revised and partly re-translated by myself.

I am, Sir, yours faithfully,

London, W., April 24th, 1916.

M. D. EDER.

\section{THREE CASES OF ANGINA PECTORIS TREATED BY A NEW METHOD.}

\section{To the Editor of THE LANCET.}

SIR, - The treatment adopted in the following three cases of angina pectoris may throw additional light on this baffling affection.

Dr. $X$, an old friend of mine, had his first attack last summer while on holiday. Before this he was strong and healthy, a rapid and untiring walker, and his heart was sound. Owing to the war he had auffered many anxieties. His appetite failed and he lost steadily both energy and weight. About a week after his holiday the second attack occurred, and from that time the attacks were more frequent and of awful severity, of ten two or three on a day; the usual remedies, nitrite of amyl, \&c., lost their effects. He then told me of his condition, calling me in to sign his last papers and save an inquest. Being laid up myself just then, I handed my friend over to a colleague, from whom he derived the greatest comfort and relief. By my advice he took absolute rest in bed for three or four weeks, and there was no return of the attacks, but he had severe after or minor pains in chest and left arm; also on the slightest exertion these pains attained ominous forebodings of a severe spasm.

During my own illness I reflected on my friend's sad state, and it struck me that, whatever the original canse, if the minor pains could be got rid of the major would not follow, and that hope of ultimate recovery would be considerable. I formed the opinion that the minor pains were due to partial constriction of the small vessels, and that the major were due to entire constriction. I then considered, mentally, a small vessel thus constricted, and that forces acting either in the line of the vessels or transversely would mechanically release the constriction, and that similar results would in general follow where there was a condition of tortuosity. Early in December of last year I again called on Dr. $X$ after some weeks, and found him in much pain in both arms and ehest. At once I got him to grasp the top bar of the bed with both hands, letting most of his weight fall on the now strongly stretched arms for some 40 seconds. After a short rest he repeated the process some five or six times. Result: Immediate cessation of all pain in arms and some relief of the chest. I now got him on the floor to grasp the bar at the end of the bed with both hands lehind his back, bending forward at an angle of about $60^{\circ}$, the chest thrown forward, and the head back, thus subjecting the muscles of the affected area to strong tension. This he repeated some half-dozen times, each lasting about 40 or 50 seconds. Result: Immediate cessation of all pains in the chest, the sense of constriction completely vanishing. He now went to his bath, and for the first time the exertion of washing caused only the merest suspicion of the old ominous forebodings of ill. For some weeks the process was continued about every two hours, the minor pains occurring with less severity and frequency; and it is important to note that on no occasion dial the stritehing fail to gine immedhate relief though the operation must have been performed hundreds of times. No medicine was taken. Dr. $X$ is now at work and able to walk with almost his old rapidity.

The next patient, aged 35, was employed in lifting heavy parcels. His attacks were severe and only ceased on inhaling nitrite of amyl. When he came to me a few weeks ago he was sufforing from rather severe minor pains. He always know whon the major attack might be expected from the increasings severity of the former. I gave him no molicino and explained to him the operation mentioned. Result: I inmodiato cessation of pains on every occasion but one, auml alsolute stoppage on three or four occasions of the major spusm that he knew would otherwise develop.

the third case was that of a French polisher, aged 52. In his case relief w $\mathbf{~ s ~ n o t ~ s o ~ r a p i d , ~ t h o u g h ~ a f t e r ~ a ~ m i n u t e ~ o r ~}$ two he described his sensation of comfort as accompanied br " "tingling and rushing of blood over his face and neck." He has also been under this treatment for some three weeks only and is able to rest in bed, which the previous patient, unfortunately, was unable to to.

$\Lambda \mathrm{s}$ to the cause, or even predisposing cause, of this affection I am of opinion that we know very little. If I were to draw a conclusion from these three cases, I should be inclined to say that, as a predisposing cause, long. continued anxiety or worry plays a large part. As to the cause of the pain, I believe that partial constriction of the vessels gives rise to the minor, and that complete constriction causes the severe, or major, attacks, and that the greater the area involved and the more absolute the constriction of the vessels the more severe is the attack. Also, that the conditions of atheroma and arterio-sclerosis, with consequent loss of arterial elasticity, are a very large factor of the pain, and that they are in no way a part of either the original or predisposing cause. We rarely hear of anyone of 60 suffering from angina pectoris, and after 65 the affection is practically unknown; so that the more pronounced the atheroma, the more immune we become. I also conclude that there is no distinction, beyond the degree of pain, between true angina and false. The child simply suffers less because better equipped with elastic tissue.

If any sufferer of $\mathrm{my}$ own profession should care to write to me for further information, I need hardly say it will give give me great pleasure to answer any questions that may contribute to his comfort.

I am, Sir, yours faithfully, SAMUEL Constable.

25, Belmont-ro3d, West Green, N , April 22nd, 1916

\section{SHAKESPEARE AND MEDICINE. To the Editor of THE LANCET.}

Sir, - You may perhaps be able to find room for the following brief notes relating to Shakespeare and medicine.

1. A medical pali-bearer.-The Evening Standard of March 15th, 1913, recorded the following inscription found upon a dilapidated tombstone in the old Masonic gravepard of Fredricksburg, Virginia :-

Here lies the body of

EDWARD HELDON

Practitioner in Physics and Chirurgery. Born in Bedfordshire, England, in the year of our Lord 1542. Was contemporary with and one of the pall bearers of William Shakespeare of the Aron. After a brief illness his spirit aicended in the year of our Lord 1618, aged 76 .

The inscription is in old English letters, dim but traceable It must be added, however, that the Evening Standard of three days later contained a letter signed "Edward $S$ Dodgson, M.A. Oxon.," throwing considerable doubt upon the authenticity of the above inscription.

2. Dr. Hall's patients. - Notes and Queries, August 28th 1915, contains a list of patients attended by Dr. John Hall Shakespeare's son-in-law and physician. This list, compiled by Hall himself, mentions "Mrs. Hall, my wife," and "Elizabeth my onely daughter," but does not mention Shakespeare.

3. A medical writer on shakespeare.-A little known but excellent work is "Shakespeare and his Times," by Nathan Drake, M.D. (1766-1836), two volumes, 4to, 1817. This work was favourably reviewed by the Gentleman's Magazin at the time of its publication. Dr. Drake also wrote (1888) "Memorials of Shakespeare," a sort of anthology of all that had been written to date upon the poet and his works both at home and abroad. Both of Dr. Drake's works are in the British Museum.

4. The oause of Shakespeare's death.-There seems to be little doubt that the poet's death was occasioned by inebriety. A month before he died Shakespeare indulged in a sym. posium with his boon companions Michael Drayton and Ben Jonson, caught a chill on his way home, and did not leave his bed again. These facts are recorded in the MS. diary of the Rev. John Ward, vicar at the time of Stratford. upon-Avon. The vicar's diary is in the possession of the 